QIJIS: Qudus International Journal of Islamic Studies

Volume 5, Issue 2, August 2017

\title{
RETHINKING THE IMPACT OF THE CRUSADES ON THE MUSLIM-CHRISTIAN THOUGHT AND DEVELOPMENT
}

\author{
Muhammad Yaseen Gada \\ Aligarh Muslim University, Aligarh-202002, (U.P.) India. \\ myyaseenm2@gmail.com
}

\begin{abstract}
The present paper attempts to revisit the impact of the Crusades into a broader social, economic, political, and religious context. It will first investigate the Crusades' impact on the Muslim world and, then accordingly and importantly on the Western Europe vis-a-vis trade, economy, religion, knowledge, scientific inventions, literature to name a few prominent areas. The Crusade imagery, ideology and symbolism are so much powerful and immense so that it has subsided and undermined the constructive/positive impact the Western Europe achieved by confronting with the Orient/Muslim world. The paper concludes that the Crusades' positive impact and interaction if broadly highlighted and explored, and if given considerable space in public and academic discourses then the possibilities of the East-West tension and hostility could be alleviated to a considerable extent.
\end{abstract}

Keywords: Crusade, Impact, Muslim, Christian, Trade, Attitude 


\section{A. Introduction}

Rich in charming episodes and dramatic events, spread over two centuries and three continents, the Crusades had immense impact on Europe, and it cannot be rejected that they continue to prevail in popular conscious today even in the Muslim world. What was their impact in the Middle East? And how and why they continue to shape and influence the modern thought? In this paper, we will consider and analyse their immediate impact both, first, on the Muslim world and then, importantly, on the Europe.

Although, it is often been argued that the Crusades had little, if not negligible, impact on the lands and people against whom it were launched in the medieval Middle East. Nevertheless, in some aspects, Muslims were influenced by these events to an extant yet less important than the Europe influenced. This has been clearly remarked by many scholars. One such scholar, Hitti (1985: 33) writes:

They [Crusades] were poor in the contribution they made to the edification or enlightenment in the area of their operation. The chain reaction of counter-crusades and of the anti-Christian and anti-western feeling they generated had not ceased. The festering sore they left refused to heal, and scars on the face of the lands and on the souls of their inhabitants and still in evidence. As late as the twentieth century the anticrusading ghost was invoked in connection with the mandate imposed on Syria and Iraq and the Anglo-French attach on Egypt in 1956.

\section{B. Discussion}

\section{Impact of Crusades on the Medieval Muslim World}

The First Crusades was the only successful war, among nine Crusades, by the Franks against the Muslims in the Levant that had resulted in the establishment of four Latin Christian Crusade states in the East. The success of the Franks was mainly due to the internal disunity and succession struggle on 
the political front among the Muslim rulers that had already divided into two major Muslim dynasties: the Abbasids (based in Baghdad) and the Fatimids (in Egypt). There were also small pretty states which dotted from Asia minor in the north to Egypt in the south. However, the atmosphere later favoured Muslims; they defeated Crusaders, especially the role played by the great Zangi's and later by their lieutenant, Kurdish commander, Șalah al-Din Ayyubi. With their success, the immediate and overriding impact of the Crusades on the Muslim lands was seen in the establishment of a united and re-awakened political and religious consciousness among the rulers and the common people alike. In fact, the religious scholars of the period played an exceptional role in motivating and raising awareness about the evil notions of the Franks on the one hand, and on the other hand, they did help the rulers to realize and apprise them of their responsibilities in defending their lands from the invading forces. Thus, started the reverse wave of disunity and chaos among the crusaders, as has been remarked (Hitti, 1985: 35):

Thus did the crusaded unwittingly contribute to reversing the centrifugal forces political Islam and to halting sectarian expansion in religious Islam. A devout Sunnite, Saladin suppressed heterodoxy, championed orthodoxy, and more than any other Moslem hero personified the counter-crusading pan-Islamic spirit. With him the disunity, incompetent leadership, and low morale which had characterized Islam at the end of the eleventh century completed the shift to the enemy's side.

This achievement is considered the first of the positive effects of the Crusades on Muslim lands both in chronology and in significance (Hitti, 1985: 36). However, one should not be preoccupied with the notion that the Crusades had only impact on the battleground-death, injury, sufferings, traumatic affairs, mutual dissent and hatred-that, in fact, is hard to forget as plenty of human and material resources vanished and destroyed. Yet the impact of the Crusades can be seen off the battlefield in various cultural and civilization domains: social; political; religion; education; and economy in the Muslim lands. 


\section{Crusade Impact on Muslim Socio-Political and Religious Domians}

\section{a. Impact on Religious Views}

The reawakened and revitalized Islamic spirit among the Muslim during the crusades as mentioned above was aroused by the onslaught of the Crusaders. This spirit can be easily found expressed in the literature of the age. As the increasing Jihād spirit was championed both by religious and military elites. Moreover, the Crusades paved among the Muslim for the production of a particular genre of literature: Jihād, fadā'il (virtues), war manuals. This new literary output which encouraged Muslims to visit the sacred places such as Makkah, Madina, Jerusalem in particular, promising many rewards-served as guidebooks and helped people to gather combat against the invading race (Hitti, 1985: 37). These treatises helped Muslim to gather more information about the new race "ifranj" (Franks) as they called them with the result Muslim interest about the Crusaders gained more impetus. Moreover, Carole Hillenbrand's view is worth to note here when she writes about the Muslim attitude towards the Franks: "The role of the religion of Islam in defining the 'otherness' of the Franks is also very significant, and reinforces the gulf between the Muslims and the Christian newcomers. Christian and Muslim communities were kept apart by something quite different from geography. It was partly each community's sense of identity and partly its sense of purpose. Both of these were expressed in terms of religion" (Hillenbrand, 1997: 283). She further goes on to say, "In the Muslim portrayal of the Franks, then, symbols of pollution and impurity abound. These reflect wellsprings of Muslim religious revulsion at a deep psychological level". One could argue here that this was not the case all time; we have ample evidences where many reputed Christian physicians of the medieval times enjoyed highly respected positions in the Caliphs court (Hillenbrand, 1997: 354). Even during the Abbasid's "Translation Movement" many Christians were invited and encouraged for the task of translation at "Bayt al-Hikmah" in Baghdad, as they were 
qualifies for the job. Yet during and after the era of the Crusades Muslims had developed new imagination about the Franks who had ravaged the Muslim lands.

\section{b. Impact on Socio-Political Level}

The religious differences and the mutual hostility on and off the battleground did not prevent the Muslims and the crusaders from entering into alliances and diplomatic ties-an important part of the international relations (Christie, 2014: 73). Crusades did help expansion of diplomatic relation between the rulers in Europe and the Levant especially during and after the Salah al-Dīn's rule. One immediate but important impact of these diplomatic relations brought people of different religions and ethnicities more closely into contact with one another as Niall Christie remarks "Muslims and Franks in the Levant attended each other's festivals, visited each other's homes and formed friendships" (Christie, 2014: 113). However, these sociocultural friendships and relations were limited and restricted to some aspects only, for religion and language were the two major obstacles in establishing longevity of these relations. Therefore, on the more personal or cultural level, Crusades had little impact on Muslim society, rather Franks were themselves assimilated to the Islamic life but "made little contribution to that life" (Hodgson, 1974: 265). Therefore, Arabs neither adopted European clothes nor preferred their food. Nevertheless, it is reported "In cairo merchants who imported western cloth occupied a special bazaar known after them by the name suq al-jauwakhin. A kind of European cloak became so popular that the 'Franks imported unlimited quantities of it'. Al-bunduqi" (the Venetian), for cloth imported from Venice, became a familiar word in Arabic" (Hitti, 1985: 39).

Muslims generally regarded the Frankish culture and all their day to day practices inferior to theirs'. In his first hand experience and most delightful observation of the Frankish culture, Usama bin Munqidh (1095-1188) presents most detailed account about the social intercourse of the Franks with 
the Muslims. He remarked "the Franks are void of all zeal and jealousy' in sex affairs; their methods of ordeal by water and duel are far inferior to the Moslem judicial procedure; their system of medication appears odd and primitive when compared with the more highly developed system of the Arabs." However, Usama praises the Franks for they possess "the virtues of courage and fighting, but nothing else" (Hitti, 1985: 45).

\section{c. Impact on Economy-Trade and Commerce}

Next to the socio-political domain, the Crusades impact on the economy was more visible on the Moslem lands, than on any other level. The diplomatic ties between Europe and the Muslims resulted in the greater presence of European merchants in the east despite various hurdles due to the wars (Hillenbrand, 1997: 391-406). It is often argued that the period of peace was greater than the period of war in the Levant; however, that might be true yet the negative impact of the Crusades-they were incredibly destructive in terms of human loss and property-was high; and this destruction cannot be undermined on the pretext of mere flourishing of trade and commerce in the east. Nevertheless, writing about the economic activity and maritime commerce of the Europe with the east, Philip Khuri Hitti (1985: 38) remarks:

Next to the political, the economic transformation was the most pronounced and important effects on Moslem lands. The crusader impact had its negative economic effects in the form of destruction of life and property, but...the periods of peace were longer duration than those of war. Trade-at least in the case of Genoese, Venetians, and Pisans, the shrewdest money-makers of the age-was a primary motivation in the venture.

He further mentions about the economic transformation that until "trade had flowen mostly from east to west, but now there was a strong reverse current, while the east-west stream was both enhanced and accelerated" (Hitti, 1985: 38). Various trade commodities, due to their high quality, of the east received fresh impetus due to the opening of more markets thus demand of these products increased as the coming Europeans developed more taste and interest in the products of the East. 
Moreover, many cosmopolitan trade centers were establishes in the east which remained busy throughout the year and became as commercial hubs both for the Franks and the Muslims. Worthy of mentioning among them were Syria, Cairo, and Beirut, Alexandria. Syria was especially important as it connected the then Europe with Asia; it operated as a middleman between the merchants of Europe and the rest of Asia: Arab, central Asia, and India (Hitti, 1985: 38).

Muslims began to import some commodities of the Europe which were scarce in the east. The imported products were silk, woolen clothes, cereals, silver, wood and iron. The last two commodities were instrumental for the war technology; these were used by the Muslims in the construction of siege weapons and ships (Christie, 2014: 76). The trade was not unidirectional but goods were exchanged between the European and eastern merchants.

Woolen fabrics from England, Flanders, France, and Italy went first to Venice or some other Italian port and thence on galleys to Syria and Egyptian ports. Venetians in Syria exchanged western for eastern glassware; Genoese and Florentines carries on the same kind of trade. Besides wool, linen was a desired commodity.... From Syrian ports, trade found its way into the interior, into Mesopotamia, Persia, and even Central Asia. (Hitti, 1985: 39).

With this brisk trading and commercial activities, eastern Muslim markets remained busy with the result the interior cities also benefited from these commercial activities paved to accumulate huge fortunes.

\section{Establishment of Trade Hostelries (funduqs)}

As we have seen that the coming of the Crusaders in the east brought warfare and destruction in the region, but at the same time, they also encouraged an increased presence of Western merchants in Egypt, Syria, and the Crusader states. In order to gain access to markets and commercial goods, these Western merchants needed both political and institutional support for their activities. It can be said that their needs were at par with 
what the local Muslim traders needed for their commercial activities. One of the immediate and important needs for theses foreign merchants was security and lodging. As we have already discussed about the diplomatic ties between the Franks and the Muslim resulted in the enactment of a number of alliances and treaties particularly during the Ayyubids and Mamluks period. One of the objectives of these treaties was the provision of safe and secure environment for the foreign merchants in the east. Thus we see, the establishment of the new merchant hostelry ("funduq" in Arabic) commercial infrastructure that remained symbolic for the long-distance trade in the east during and after the period of Crusades.

Merchants, traders, travelers or pilgrims need both shortterm and long-term lodging facilities for themselves, commercial goods and their animals. Muslim medieval world already had these facilities, as they were conversant with the trade and commerce with the rest of the world. They had waqf (endowments), funduqs, khans (in Persian) or caravansaries that provided all these, apart from other, facilities both free of cost and sometimes with charges. However, the European presence in the east brought sudden changes both in number and function in the funduqs. These changes were all made with the approval of local Muslim rulers; and this helped Muslim authorities to control the foreign merchants visiting their land in a good and hospitable manner.

\section{Impact on Art and Architecture}

It is one of the debatable questions of the crusader impact on the art and architecture of the Muslim lands. Scholars believe that it is not always possible to say firmly that Muslims borrowed from the Franks in architectural design. Yet when one examines and analyses the surviving artistic and architectural material from the crusading period, one gets interesting insights from this examination of the material. One scholar, Oleg Grabar (2001: 238), goes on to say, "It is more difficult to detect a visual or formal impact of the Crusades on arts other than architecture". 
We know the arrival of the crusaders in the Levant was simultaneously accompanied by the establishment and construction of big castles, fortresses, churches, towns. Fortified castles were the major development of the crusaders in the east. Although, it is difficult, according to Hillenbrand (1997: 382), "to access the impact of the crusader presence on the building activities of the Muslims"; however, one would easily expect that Muslims would also had responded by similar construction of great castles to defend their lands.

When Muslims defeated the crusaders, Muslims took control of the crusader castles, fortresses-both ruins and intact. Muslims build their own castles and forts, "reusing fragments of crusader stonework in Islamic religious monuments" (Hillenbrand, 1997: 382). There are evidences of reuse of the crusader sculpture in Islamic monuments especially in Palestine such as the arches of the facade in the Aqsa mosque are said to have sculpted ornament of twelfth century crusader structures. Similarly, the upper part of the fountain at the Bab al-silsila, where the pendatives of the domes are believed to have reconstructed by Ayyubids from crusader pieces. Moreover, the beautiful doorway taken from the church of Acre was brought in 1291 and incorporated in the complex (mosque) of Muhammad al-Nasir (ca. 1303) in Cairo; represent the most artistic relic of those days.

More examples of the integration of crusader stonework in Muslim monuments of the Mamluk and later periods abound in Jerusalem, Hebron, Bethlehem, Beirut, and Tripoli. From these examples one could easily reach to the conclusion that the art of the crusaders had impact on the Muslim world as crusaders did leave traces of their architecture; however, as Grabar (2001: 238) tells "these traces are, relatively speaking, minimal...and almost any of them is a unique case which can be explained through special circumstances". This is an important comment from the scholar who has extensively researched on this aspect of the crusades. He takes great pains at exploring the hitherto neglected area-impact of Crusades on Muslim art and architecture; until 
now numerous extensive studies have been conducted on the reverse side: crusades impact on European art and architecture, which will be discussed shortly in the paper.

Similarly, the crusader impact on minor arts, "On the levels of exchanges of forms or of affecting artistic creativity directly and immediately, there is not"; for "Crusades hardly mattered in the artistic life of the Muslim world" (Grabar, 2001: 239). "But on the whole, in architecture as in other fields, the crusaders borrowed more than they lent" (Hitti, 1985: 44). Summing up the impact of the Crusades on the Islamic World, famous historian, David Nicole (2001: 64-65), in his The Crusades, remarks, "The impact of the Crusades upon the Islamic world was minimal and localised. Indeed, the whole Crusading episode was of far less importance to the Islamic world than is generally recognised.... The Islamic Middle East's trade with Europe had in any case been of secondary importance compared with trade to the east and perhaps even south".

Thus, from the ongoing discussion one should not get impression that, in fact, crusades had great impact on the East/Muslim world; however, it should, at the same time, borne in mind that the golden age of the Medieval Islamic civilization had just receding after enjoying a great deal of prosperity and was continue to see it flourishing, if not in the Levant, of course, but in the far off places away from the Arab world.

\section{Impact of Crusades on Western Europe}

The tangible impact of the crusades on the Muslims is unnoticed and one can hardly find any lasting transformations to the local population of the region. However, on the other side, the impact of crusades on Europe is, undoubtedly, of tremendous mark and profound influence on every level of Western European civilization (Gec, 2006). This section will now shed light on the crusades impact on Europe itself that had launched it both inside and outside the Europe.

The crusades are considered one of the most liaison points where influence or copying took place between east and west. 
Crusades were also the turning point for Europe (Curry, 2003: 69), as Europe was passing through its darkest periods of its history and on the other hand, Muslim were enjoying a commonwealth and cosmopolitan civilization flourishing far and wide when the West began to look into the eyes of the Islamic civilization by launching war-crusade-on the Islamic world which lasted for about two centuries. During and after the crusades, Europe continued to take benefits from the east that ultimately paved Europe to development and prosperity. Lebon (1974: 334), in his The world of Islamic civilization, says:

The link between the Occident and the Orient for two centuries was one of the strongest factors for the development of civilization in Europe... those who want to know the influence of the Orient on the Occident have to understand the state of civilization of the peoples of both sides. As the Orient was enjoying flourishing civilization thanks to the Arabs, the Occident plunged into barbarism.

\section{Economic Impact on Europe}

The economic impact of the crusades on Europe had longterm influence on the Europeans' economy and attitude towards living and thinking. Although the Christian-European merchants, before the crusades, were already engaged in trade with Egypt and Tunisia; (Cook, 1970: 7) however, once the crusaders settled in the Syria they invaded during the First Crusade, their strategic positions lies close to trade route of the East. As a result they were more exposed to Eastern markets such as Damascus, Alexandria, and Baghdad with all of their high quality goods mostly spices, metal work, paper which greatly appeased the Crusaders. Moreover, the settled Crusaders and their successors had to depend on Europe for certain other essential commodities and supplies such as horses, armour, cloth, and the like, which were scarce in Eastern markets, gave boost to the European trade which grew with rapidity (Newhall, 1969: 101-102). 


\section{Merchant goods and Trade}

Crusaders, pilgrims, businessmen, and sailors returning from the East brought back knowledge of new products and interests, which they had learned to enjoy during their stay. As a result of this new thinking and living, new demands and new markets were created in the West of which enterprising merchants sought to benefit themselves. The introduction into Europe of new articles of commerce, new natural products, and new commercial practices by way of this Muslim trade is clearly marked by the words borrowed from the Arabic, which appeared during the crusading epoch. Goldwork, ironwork, the manufacture of swords, silk, and soap, and the weaving of rugs flourished as never before (Hitti, 1985: 38). Moreover, fine glass objects found their place in European cathedrals, churches, or abbeys where they were considered to be gifts from the Crusades; and varieties of Syrian glass became the forerunner of the stained glass in the cathedrals of Europe as "Syrian glass and Metal vases were in great demand as articles of utility and luxury" (Hitti, 1970: 346). Some Syrian glass objects have been unearthed in the Crusader Castle of Montfort.

Oriental textiles were in great demand in Europe, started to arrive to Europe in large quantities, which would be made into luxurious vestments for the European people. Fabrics such as muslin (from Mosul), baldachin (from Baghdad), damask (from Damascus), sarcenet (from Saracen), atlas (atlas), velvet, silk, and satin came to be more appreciated and were increasingly in demand. Franks in the orient developed new interests and tastes, especially in perfumes, spices-pepper, ginger, cloves, cinnamon; sweetmeats, attar ('itar), zinger (Zanjabil), sugar (Sukkar), rare luxuries in eleventh-century Europe, came to it now in delightful quantities (Hitti, 1970: 665, 667). New plants, crops and trees, vegetables and fruits, famous among the Muslim people, appeared, such as sesame, maize, carob (kharrub in Arabic), millet, rice, lemons, melons, apricots (sometimes called plums of Damascus), and garlic (shallot, that is, little onions of Ascalon), and products 
of India and Arabia-dyes, powders, gems, and scents-had to be satisfied on behalf of returning crusaders through commercial channels (Hitti, 1970: 665, 667).

New desires and tastes of Eastern commercial commodities especially in matters of fashion, clothing and home furnishing promoted new demands in the European markets. Hitti has put it, thus, "Returning crusaders introduced into their homes the rugs, carpets and tapestries of which Western and Central Asia had for long made a speciality...." (Hitti, 1970: 668).

It would not be an exaggeration to say that the crusades infused a secular life in Europe by acquaintance with Moslem commerce and industry. "War does one good", says Durant "It teaches people geography". In this way the crusades guided the enthusiastic Italian and other European merchants to make good charts/maps of the Mediterranean primarily to make their access to the commercial hubs of the Levant safe and easy for their trade; and it was the material interests that attracted mostly the Italian businessmen to travel to the east on the pretext of the Holy war for they cared and showed little interest in these crusade wars. In light of this it can be argued that the crusade war was itself guided by trade for Durant (1950: 486) has discussed on detail how crusades benefited Europe in trade and commerce.

Similarly, the opening of new markets in the East with all of its new commercial articles and industrial products greatly fostered Europeans' desire to reach their sources, which resulted in the development of international trade between east and west. In other words it can be said that the age of discovery by European ships, the zest for exploration and travel, and roaming the world looking for India or Mocha, have been inspired by the descriptions of Crusaders to the Holy Land. The crusades, moreover, paved among Europeans the new conception of the vastness and variety of Asia; merchants and businessmen eager to exploit new rich markets of the East, eventually led to the development of the modern Europe. 


\section{Impact on Trade Currency and Banking System}

The new economic situation, which was brought about by the Crusades, necessitated new financial needs, currency exchanges, and more so a full-fledged banking system. It demanded a larger supply and a rapid circulation of money. Moreover, the problem of differences of exchanging of European currency with that of hard-metal currencies of the East earned substantial loss to the Europeans. Therefore a system of credit notes was formulated to ease the international trade and transactions. In this way, a complete international banking system emerged with active firms of bankers arose in Genoa and Pisa with many affiliated branches functioning in the East. The Crusade Templars began to use letters of credit, and began to perform all other banking functions: receive money on deposit and lend it back on interest. It is reported that the earliest gold coin was minted by Venetians in Palestine and bore the Arabic inscriptions (Hitti, 1970: 669).

Hitti (1985: 40) has emphasised the two common terms in finance to testify this international trade relationship that developed due to the crusades and continued after the postcrusading period. He writes that english "check" is related to Arabic word sakk", similarly the Arabic word "ghirsh" (colloquial, qirsh), is still used for a unit of currency, was actually borrowed from German Groschen through Turkish.

Thus, the crusades made the international trade more vibrant. Traders and merchants did business, but Europe got the benefits: earned tremendous profits in different ways. First, the social position of the merchant class became better; it was going up that brought about the growth of cities and better living conditions. The Italian commercial activities were profoundly stimulated, and the east-west trade between the ports of Syria and those of Italy enjoyed a great revival. Second, the economy of Europe boosted, became active, vibrant system of international banking developed and the first gold coins were minted that brought the long period of barter system to an end which was 
substituted with a period of money and credit that in turn brought the enormous growth of the Levantine trade and the free movement of travellers and traders.

\section{Impact on Architecture}

Like in other fields, Crusades had also impact on European architecture. The returning crusaders, merchants, pilgrims, and mostly the Normans and the Italians, to the West brought with them the knowledge of Eastern and Muslim architecture. The Muslim or Near Eastern influence was not only on the local European settlers-art and architecture-in the Holy Land but instead what they brought back with them. There is no denying the fact that most of the Islamic influence on the Europeans came through Spain and Sicily before the actual crusades began in the eleventh century. Nevertheless, the crusades also contributed to accommodate the particular forms of Eastern architecture and have had its influence visible such as on military masonry, castles, churches, forts and other Christian buildings in the West Europe. In Britain, the crusade-themed images and stories were used to decorate the artistic motifs of religious buildings such as the abbeys of Chertsey, Neath, Tintern, Glastonbury and Cleeve all had floor tiles depicting the duel of Richard I and salah al-din (saladin). The use of crusade-themed images was recognised as noble tastes, as images reflecting crusade events were popular with the English Crown. The round-naved churches and chapels first appeared in the twelfth and thirteen century in Western Europe in imitation of the church Sepulchre of the Eastern Mediterranean (Hurlock, 2013: 121-122).

Moreover, Gothic architecture is said to have been influenced by the Islamic architecture. The introduction of the pointed arches in Europe coincides with the Norman invasion of the Islamic Sicily in 1090, the Crusades which began in 1096, and the Islamic presence in Spain, brought about a knowledge of this significant structural device. In addition, decorative carved stone screens and window openings filled with pierced stone also 
influenced Gothic tracery. Atiya (1962: 127) credits the crusades for bring the means through which the transfer of Eastern art to Europe took place:

Crusading artisans and masons watched with wonderment the splendid stone carving and moulding in which the Syrians had excelled from antiquity; and they returned to their homes with new artistic ideals, to lay the foundations of the elaborate Gothic style in Europe. The Arab formulae for the manufacture of stained and enamelled glass and of the Damascus steel blade, hitherto kept as close secrets, were transmitted to European factories during the Crusades.

In Spain, in particular, individual decorative patterns occur which are common to both Islamic and Christian architectural mouldings and sculpture (Shah, 2011). Generally, Europe imported various Islamic art and architectural forms and techniques such as the use of bronze and ivory for relics or churches, the very Syrianstyle Islamic mausoleum built for the Norman prince, Bohemond, the random imitation of the Arabic script found all over medieval art, and, especially, textiles are all visible examples of the influence that was left on Crusaders and Europe. Together with this, the symbolic Holy land may well have affected the architecture of late Romanesque cloisters. In nutshell, it is notable that "the presence of Islamic forms was greater in the West than of Western forms in the Islamic world" (Grabar, 2001: 239). Thus overall, the crusades brought visible changes, as new forms, styles, patterns, images, and stories, were incorporated into the local Western architecture especially the religious, military, and armour architecture.

\section{Impact on War and Military Technology and Practice}

One more area in which the crusades impact on the crusaders and the West is more evident in the military technology and practice. Aziz S. Atiya (1962: 125) claims that the Crusades had a considerable influence on the medieval military system in Europe through direct contact with other cultures-Greeks and Arabs. In the face of the perpetual danger, the crusaders were 
susceptible to improvement of their art of war. This further suggests that, like in other areas, in general, military-technological terms, the crusaders were no more advanced than either the Byzantines or Muslims, and, indeed, may in fact have been inferior in some respects (Nicolle, 1992: 335). Among other features of technology, technique and practice acquired by the crusaders from the east, as stated and detailed by Atiya (1962: 125-126), one was the introduction of machicolation in military structures. This was predominately an important feature of Eastern war technology that could be easily found in the castles, fortified walls and buildings of Egypt and Jerusalem before it was adopted and transferred to the West by the crusaders.

Moreover, different Eastern weaponries such as a distinct angled-forward conical helmet, hardened leather armour, the bascinet helmet, coat-of-plates, and larger daggers, were among other items which came to be used by the crusaders that have been inspired by Byzantine or Islamic influences (Nicolle, 1992: 335). Some historians, while acknowledging the adoption of "oriental war technology" by the crusaders, however, they argue that "Crusader arms and armour were different" to those of either the Byzantines or Muslims (Prawer, 1986: 31). On this, it could be said that no doubt the crusaders continued to look different to their enemy, nevertheless, it is wrong to assume that the crusaders who settled in the Levant or even those who went back to Europe were completely immune to the Eastern influence of superior cultural elements which, of course, also included the war techniques and practices. Therefore, it is fare to say the crusaders, and the medieval military system in general, appear to have promoted and benefitted from contact with other superior cultures in the Levant, while the benefit to these other cultures was more limited as Hitti (1985: 44) acknowledged states "the normal flow is from the higher to the lower, and this case was no exception". 


\section{Impact on European Culture and Society}

Crusades entailed, apart from war and fighting, a perpetual direct contact with the Eastern culture of the Levant-Roman and Muslim. They lived in the new culture, enjoyed and acquired it. The cultural impact was manifested and visible in the lifestyle of the crusaders changed as they were living and accommodated in the new atmosphere-different in look and taste. They were thrilled and surprised by the highly developed and hygiene lifestyle of the East. It is in the area of eastern lifestyle especially the clothing, cuisine, hygienic facilities the cultural influence was far reaching and it was inevitable for them to adopt it.

Historians have acknowledged that the West learnt the use of hygienic system from the Muslims when they first came into contact, as a result of Crusades, with the Muslims of East as Atiya (1962: 127) has put it "Contacts with a highly superior [Muslim] civilization taught these rough warriors [crusaders] the use of public and private baths. It was by the same channel that Europe first became acquainted with, and, thus adopted, the use of latrines". According to Holmes (1977: 18-19), the eastern bath was quite famous among western Europeans, including monks and nuns. Oriental romances-dress, cuisine, language-flowed into Europe, and found new dress, food in the nascent vernaculars.

It is safe to say that the crusades had a powerful effect, by and large, on the development of Western European society. And this development took place mainly because of two inter-related events: the sudden broadening of cultural horizons because of the mass flow of people from the Western Europe to the Holy land, and the crusaders' acquaintance with and adoption of the intellectual legacy of the Muslims and the Greeks of the East resulted in the broadening of human and knowledge horizons. Moreover, "the adventurous spirit" of the crusades, in the words of Atiya (1962: 127), "ultimately brought forth the age of exploration and discovery" for the Western Europe. And similarly, the East-West close proximity brought about by the crusades, let the Europeans 
to learn and gain knowledge of science, philosophy and literature of the Muslim East.

In the medieval Western Europe, it was impossible for an individual to gain expertise and to become a fully-fledged mathematician, astronomer, physician, philosopher, to name a few, without a good knowledge of Arabic, which certainly developed a lingua franca. For this reason, a number of crusaders learnt the language of Islam, Arabic, and it potentially contributed to the enrichment of the European civilization (Hitti, 1970: 47-48). The compass, gunpowder, and printing of paper, and numerous other invention that followed, were known in the East before the Crusades ended, and have come to Europe in the backwash of that tidal wave-the Crusades (Durant, 1985: 22-23). Atiya (1962: 127) points to, quoting Gibbon, "the first importer of windmills from Asia Minor as one of the benefactors of the nations of Europe".

It is true that Muslim influences in such fields such as literature, science and technology, and philosophy, by and large, came rather through two gates: Muslim Spain and Sicily as mentioned earlier, than through the mere contact of these wars; however, as we know the returning Palestinian Franks to Europe brought with them many of Muslim scientific learning. The Franks in the east, in fact, learned from the Muslims at an everyday level; acquired not only various cultural traits but they also were influenced by the great achievements of Muslim learning.

Helen Nicolson (2004: 95), a famous Crusade historian, acknowledges the Crusades' influence on European literature, he writes:

Literature was not far from that impact as the Seven Sages of Rome fictional stories written in French, and written in the second half of the thirteenth century, was heavily influenced by oriental traditions...including the work of Boccaccio's Decameron and Dante's Commedia, under medieval European literature, influenced by Arab literature through the Crusaders.... European literature has also been inspired, in whole or in part, by the crusading wars between Christians and Muslims, such as the Chanson de Roland. Lastly, the Crusades in the Holy land were without doubt the basis of a whole French cycle of stories known 
as the Crusade cycle. These epics gave birth to later work, such as the sixteenth century romantic poem, la Gerusalemme liberate, that inspired many adoptions and imitations.

There were admirers of this great Islamic civilization, among the crusader leaders who had great love and taste for the literary and scientific aesthetics; patronised Muslim intellectuals in Europe. Emperor Frederick II of Hohenstaufen (the Roman Emperor from the papal coronation in 1220), who enjoyed philosophy, logic, medicine, and mathematics discussion with Muslims. Moreover, he established, at Lucera, a colony of Arabs in his service, with their own mosque and all aspects of eastern life Schacht (1974: 24). Similarly, medieval Crusade historians like William, Archbishop of Tyre, spoke of Muslim civilization with such a respect and an admiration, Durant (1950: 485) claims that would have "shocked the rude warriors of the First Crusade".

In the Middle Ages, these wars (Crusades) inspired not only chroniclers but they also poets and literary persons, though on partisan lines, who produced a rich collection of literature in English and other European languages. The literature produced is still acclaimed and approached with great admiration in all quarters of literary world.

Summing up the Islamic influence on the development of Western Europe, in the words of the well-known Bernard Lewis (a British-American historian specializing in oriental studies, born in 1916), in his recent work has put it, Islam "had achieved the highest level so far in human history in the arts and sciences of civilization...[intellectually] medieval Europe was a pupil and in a sense dependent on the Islamic world"; however, Europeans suddenly began to advance "by leaps and bounds, leaving the scientific and technological and eventually the cultural heritage of the Islamic world far behind them" (Lewis, 2002: 6-7).

\section{Impact on Religious Institutions: Church and Papacy}

Initially, the power, prestige and role of the Roman church and Papacy were immensely enhanced and strengthened due to 
the success of the First Crusade, but later progressively damaged by the subsequent Crusades. Prior to the crusades, the Western Europe had suffered pain from internal struggles and conflict; the Church had lost its true image in the sight of the common people as the feudal system was controlling the whole affairs in the Medieval Europe. Therefore, the Papacy saw in the opportunity of the Holy Land and wittingly transform the request call from the Byzantine Emperor into his most momentous and successful religious drive which raised the status and authority of the Church in new heights. Moreover, the earlier Crusades gave rise to military orders - the Templars, the Hospitallers or Knights of St. John, and the Teutonic Order - that continued to play important roles in Europe, and importantly brought nobles and powerful kings into service of the church. The earlier crusades had also stimulated the demand for relics and indulgences (Lindberg, 2006: 70).

However, the failure in the remaining Crusades deteriorated and lowered the prestige, role and status of the Church and the Papacy. There were various reasons for this state of affairs. The crusades were now no longer fought, even if it is argued do; nonetheless, for the protection of the Christendom, but for the establishment of the supremacy of the Papacy.

Another element that contributed to the criticism of the Church was the need of the funding in order to finance the crusaders. In this way, many landowners, to fund their crusade, "sold or mortgaged their property to churches or monasteries to raise liquid funds" (Durant, 1950: 486), in turn led churches and monasteries acquired huge property and vast estates. When the crusades failed, the church's wealth became a ready and easy target of kings, emperors, royal envy, popular resentment, and critical rebuke.

Similarly, a key point to the utmost dissatisfaction and bitter legacy of resentment over Papacy and thus Christianity was the sack of Constantinople (the Greek Eastern Christian capital and centre) during the Fourth Crusade. Although, as we know, in reality, the Crusades had begun as a Christian attack on 
the Muslim world; however, on the contrary, "the Latin capture of Constantinople in 1204 left a legacy of bitterness between eastern and western Christendom that was, at times, even stronger than the antipathy felt by Muslims and Christian toward each other" (Greene, 2000: 6). This led to the large distrust between East-West or Greek-Latin Christians and the weakening of the Byzantine Empire. Additionally, the influence of the crusades on the church was the growing hostility between the religious and the secular, between the East and the West-Christianity, and the weakening of the Christian belief especially after the fall of the Jerusalem to Muslims, and due to the failure of each new crusade. The skeptics emerged, with the result of the crusades failure, in the belief the Pope as the true representative vicar of God on earth; even "many Christians began to blaspheme", claiming that God was favouring the Muslims (Stark, 2009: 247). Moreover, "The encounter with non-Christian culture called into question the universality and uniqueness of the church, and stimulated theological reflection" (Lindberg, 2006: 70). In short, Papacy lost its glory and power as Crusades were misused for their selfish political purposes that ultimately seriously discredited the papacy.

\section{Impact on Feudal System}

The crusades brought vivid changes in the medieval Western European feudal society. The crusades had powerful impact on feudal society; it led to the slow process of transformation where national monarchies were gradually beginning to develop, and the Papacy was showing signs of decay. In other words, the central power of the monarchy was developed at the expense of the feudal nobility. As we discussed earlier, the need for financing of their crusades in an expensive war overseas diminished aristocratic influence at home as nobles and landlords mortgaged their property or sold their rights, and went on the crusades to the East but were unable to return to their homes, forfeited their property and estates to the Church or Crown (Atiya, 1962: 124). Consequently, along with the rise of trade, and while feudalism 
was just beginning a long process of decline-the drain on feudal lands and properties made possible the new middle class slowly coming into existence. It contributed a new political role for towns, and the rise of a "third estate", (Lindberg, 2006: 70) the bourgeoisie, especially in France as Atiya (1962: 124) writes, "Townsfolk or burgesses purchased their franchises from the hard-pressed nobles going on Crusade, and allied themselves with royalty for defense against future feudal encroachments of local liege lords".

In fact, it was the encounter and the establishment of big estates in the orient that contributed to the social awakening among the Europeans after coming into the contact of the superior Islamic and Byzantine civilizations of the East. Those who gained resources were eager to expand and extend their estates both in and out of the Western Europe, and "It was the societal dynamism that erupted in the eleventh century, and in which the Crusades played a big role, which irreversibly modified the feudal system from one that was dominated by an imperial state and bureaucracy to one where various institutions - primarily the church - began a process of grant distributions" (Ghazzal, 2005: 75).

\section{Impact on Attitude toward Muslims}

Historians are unanimously agreed on the point that the crusades brought a considerable change in social, political, economic, and religious elements of the medieval Western Europe. Although, the crusades profited a first-hand experience of the Near East through the waves of Crusaders who went to and from that region, and the returning crusaders brought with them various products, cultural traits, knowledge, thought and memories which had a powerful positive influence on the Western society. However, there were yet certain things which negatively impacted and continue to do so, on their thought, attitude and imagination about Muslims. The image of a Muslim that had been implanted right from the inception of the crusades when Pope Urban II gave an emotional sermon before a large gathering, termed Muslims as 
an alien and evil race. The same perception continued to howl and hank on the ears and minds of Europeans as the Crusades went on. Furthermore, the perpetual and repeated defeat and loss in the crusading movement inevitability contributed to the development of hatred and hostility toward the Muslim community.

Eventually, a negative imagination of Islam and Muslims proliferated among the Europeans as the time went on after the fall of Jerusalem to Muslims. This point has been acknowledged by a number of scholars as they believe that "the impact of crusading on other cultural and religious groups is an area of study attracting considerable attention at present. The nature of Christian-Muslim relations has highest profile because contemporary political circumstances have brought the conflict between the crusaders ant the Muslim world to the fore" (Phillips, 2004: 4).

\section{Conclusion}

What emerges from the above discussion is that the crusades influenced and impacted both East and West. However, the impact on the East, against whom the crusades were launched, was negligible when compared and contrasted with that of the West. The crusades had both positive and negative impact when the Western society is thoroughly examined. Among the crusaders who went to the East to capture Jerusalem and to fight the Muslims, many returned back with new oriental products, knowledge, thought, culture, religion and overall the first hand experience of the Near East which was enjoying a superior civilization. The direct contacts with the orient had a long-term impact on the European culture, art, architecture, literature, science and technology. The human and cultural horizons were greatly widened and enhanced as they explored the rich Islamic and Byzantine civilizations of the East. The Western commercial trade and economy expanded and boosted and became more active; reached new heights. It would not be an exaggeration to say that there were explosion and expansion in trade, knowledge, 
territories. New scientific inventions and adventurous discoveries enabled Europe to stand with the great powers of the world.

The Crusades also negatively impacted the MuslimChristian relations-widened the gap, and led to the mutual hatred and hostility. In addition, Christianity also got fractured into two factions: Greek and Latin. The state-church discontent also emerged; feudal society was replaced by the monarchical power at the expense of papacy as the new middle class emerged to take part in the state affairs.

In conclusion, we can say that the crusades were indeed "a turning point for Europe, pushing the continent out of an isolated Dark Age and into the modern world", and they contributed in the "New Europe the Age of the Renaissance, the Age of Discovery, and the Age of the Reformation".

Last but not the least, the impact of the Crusades included both constructive as well as destructive elements (Stathis, 1995: 20). In general, the hostile contacts between the Crusaders and the Muslim world provided ample opportunities for, other more, positive relations: both commercial commodities and ideas and sentiments were exchanged. 


\section{REFERENCES}

Atiya, Aziz. S. 1962. Crusade, Commerce and Culture. Bloomington: Indiana University Press.

Christie, Niall. 2014. Muslims and Crusaders: Christianity's Wars in the Middle East, 1095-1382, From the Islamic Sources. London and New York: Routledge.

Cobb, Paul M. 2014. The Race for Paradise: An Islamic History of the Crusades. New York: Oxford University Press.

Cook, M. A. (ed.) 1970. Studies in the Economic History of the Middle East: from the rise of Islam to the present day. New York: Oxford University Press.

Curry, Andrew. 2003. "The First Holy War”, Mysteries of Faith.

Durant, Will. 1950. The Story of Civilization: The Age of Faith, vol. 4, 11 vols. New York: Simon \& Schuster. . 1985. The Story of Civilization: The Age of Faith; John R. Mott, The Muslim World of To-Day. New Delhi: Inter-India Publications.

Geç, Çok. "Crusades in the Middle East: the Impact of the Holy Land Crusades on Europe", All Empires: Online History Community, 1 November 2006, http://www.allempires. com/article/index.php?q=crusades_impact_europe (accessed on 23 November 2015).

Ghazzal, Zouhair. 2005. "The Ulama: Status and Function”, in $A$ Companion to the History of the Middle East, ed., Youssef M. Choueiri. UK: Blackwell Publishing.

Grabar, Oleg. 2001. "The Crusades and the Development of Islamic Art", in The Crusades from the Perspective of Byzantium and the Muslim World, ed., Angeliki E. Laiou and Roy Parviz Mottahedeh. Washington, D.C.: Dumbarton Oaks. 
Greene, Molly. 2000. A Shared World: Christians and Muslims in the Early Modern Mediterranean. Princeton, New Jersey: Princeton University Press.

Hillenbrand, Carole. 1997. The Crusades: Islamic Perspective. Edinburgh: Edinburgh University Press.

Hitti, Philip Khuri. 1970. History of the Arabs: From the Earliest times to the Present, tenth edition. London: Macmillan Press.

1985. "The Impact of the Crusades on Moslem Lands", in The Impact of the Crusades on the Near East, eds. Norman P. Zacour and Harry W. Hazard, in A History of the Crusades, 6 vols., ed. Kenneth M. Setton. London: The University of Wisconsin Press.

Hodgson, Marshall G. S. 1974. The Venture of Islam, 3 vols. Chicago and London: The University of Chicago Press.

Holmes, U. T. 1977. "Life Among the Europeans in Palestine and Syria in the Twelfth and Thirteenth Century", in $\mathrm{H}$. W. Hazard, A History of the Crusades vol. IV: The art and architecture of crusader states. Madison.

Hurlock, Kathryn. 2013. Britain, Ireland, and the Crusades, c. 10001300. UK: Palgrave Macmillan.

Lebon, Gustav. 1974. The world of Islamic civilization. New York: Tudor Publishers.

Lewis, Bernard. 2002. What Went Wrong? Western Impact and Muslim Eastern Response. New York: Oxford University Press.

Lindberg, Carter. 2006. A Brief History of Christianity. UK: Blackwell Publishing.

Newhall, Richard Anger. 1969. The Crusades. New York: Holt, Rinehart and Winston.

Nicholson, Helen. 2004. The Crusades. Greenwood Press. 
Nicolle, David. 1992. "Arms and Armour", in B. Z. Kedar, ed., The Horns of Hattin. Jerusalem. 2001. The Crusades. UK: Osprey Publishing.

Phillips, Jonathan. 2004. "the Crusades: sources, Impact and context", in The Medieval Crusade, ed., Susan Janet Ridyard. UK: Boydell Press.

Prawer, Joshua. 1986. "The Roots of Medieval Colonialism”, in V. P. Goss, ed., The Meeting of Two Worlds: Cultural Exchange between East and West during the period of the Crusades. Kalamazoo.

Schacht, Joseph \& C. E. Bosworth. 1974. the Legacy of Islam, 2nd edition. Oxford Clarendon Press.

Stark, Rodney. 2009. God's Battalions: The Case for the Crusades. New York: HarperCollins.

Stathis, G. Michael. 1995. "The Crusades: A Modern Perspective on the 900th Anniversary of the Event" (lecture delivered at Southern Utah University, Utah, November 30, 1995).

Zia H. Shah, "Islamic contributions to Medieval Europe", themuslimtimes.info, December 11, 2011, retrieved on 22 December 2015 from http://themuslimtimes. info/2011/12/11/islamic-contributions-to-medievaleurope/; 